\title{
A mitralis billentyú sebészete atrioventricularis septumdefektusban
}

\author{
Hartyánszky István dr. - Bogáts Gábor dr. \\ Szegedi Tudományegyetem, Általános Orvostudományi Kar, Szent-Györgyi Albert Klinikai Központ, \\ Belgyógyászati-Kardiológiai Központ, Szívsebészeti Osztály, Szeged
}

\begin{abstract}
A veleszületett szívbetegségek egyik gyakori formáját jelentő atrioventricularis septumdefektus korrekciós mútétjének kritikus pontja a közös atrioventricularis szájadék elválasztásával a mitralis billentyú kialakítása. A korrekció sikere számos anatómiai variáns függvénye, ezért nem lehet minden esetben a tökéletes anatómiai viszonyokat kialakítani. A fennmaradó billentyústenosisok, regurgitatiók a későbbi életkorban progressziót mutatva olyan hemodinamikai kórképeket, keringési elégtelenséget okozhatnak, melyek további beavatkozásokat igényelhetnek. A mitralis billentyúnek az atrioventricularis septumdefektushoz társuló betegsége koraszülöttkortól aggkorig minden életkorban előfordul, más-más mútéti megoldást igényelve. A szerzők részletezik a különböző életkorokra vonatkozóan a napjainkban lehetséges és szükséges mútéti megoldásokat, sebészi kihívásokat. A mitralis billentyű múbillentyưre történő cseréjében a klasszikus sebészi megoldások mellett napjainkban új beavatkozásokként jelentôs számban jelentkeznek a katéteres intervenciós és hibrid megoldások. A felnőttkort egyre nagyobb számban megélő betegek fokozott odafigyelést, speciális ellátást igényelnek a kardiológusoktól, szívsebészektől.
\end{abstract}

Orv Hetil. 2021; 162(35): 1397-1401.

Kulcsszavak: atrioventricularis septumdefektus, a mitralis billentyű sebészete

\section{Mitral valve surgery in the treatment of atrioventricular septal defect}

The critical point of the atrioventricular septal defect correction is to separate the common atrioventricular orifice, which results in the reconstruction of the mitral valve. The success of the correction depends on many anatomical aspects, therefore a perfect anatomical outcome is not always possible. The remaining valvular stenoses and regurgitations, showing progression at a later age, may result in hemodynamic disorders and circulatory insufficiency that may require further interventions. Mitral valve disease associated with atrioventricular septal defect occurs at all ages from preterm to adulthood, requiring different surgical solutions. The authors detail the possible and necessary surgical solutions and surgical challenges at different ages. In addition to the classic surgical solutions, a significant number of catheter interventional and hybrid solutions are emerging as new interventions in the replacement of the mitral valve with an artificial valve. An increasing number of patients living in adulthood require increased attention and special care from cardiologists and cardiac surgeons.

Keywords: atrioventricular septal defect, mitral valve surgery

Hartyánszky I, Bogáts G. [Mitral valve surgery in the treatment of atrioventricular septal defect]. Orv Hetil. 2021; 162(35): 1397-1401.

(Beérkezett: 2021. február 2.; elfogadva: 2021. február 25.)

\section{Rövidítések}

$\mathrm{AV}=$ atrioventricularis $\mathrm{AVD}=$ atrioventricularis septumdefektus; CAVD $=($ complete atrioventricular septal defect $)$ teljes atrioventricularis septumdefektus

Az atrioventricularis septumdefektus (AVD) komplett és inkomplett formája a veleszületett szívhibák 5\%-át képezve jelentős helyet foglal el a congenitalis szívsebészet mútéti palettáján. Az újszülött-, kora csecsemő korban súlyos keringési elégtelenséget okozó szívhiba korai sikeres sebészi kezelésének eredményeként napjainban egyre nagyobb számban érik meg e betegek a felnőttkort, és így jelentős kihívást okoznak a betegség kezelésében a kardiológusok, szívsebészek számára. Dolgozatunkban azokat a problémákat és sebészi lehetôségeket foglaljuk össze, amelyek az AVD korrekciója során kialakított mit- 
ralis billentyú betegsége kapcsán jelentkeznek az élet során úszülöttkortól aggkorig.

A teljes atrioventricularis septumdefektus (CAVD) komplex szívfejlődési rendellenesség, amelynél elmarad a szívcső fejlődése során az atrioventricularis (AV) billentyứk kifejlődését alkotó „párnák” egyesülése. Ennek következtében hiányzik a pitvari primum septum, a kamrai septum beáramlási része, és nem különülnek el az AV billentyúk, közös szájadékot alkotnak. Ez többszörösen befolyásolja a kialakult keringést. A primum pitvari sövény és a beáramlási kamrai sövény hiánya jelentős baljobb söntöt idéz elő, pulmonalis hypertoniát okozva. A két AV billentyú elkülönülésének hiánya a billentyúk kisebb-nagyobb elégtelenségeihez vezethet, melyek tovább súlyosbíthatják a keringési elégtelenséget. További problémát jelent a bal kamrai kiáramlási pálya speciális szúkülete, a „gooseneck” (libanyak) tünet is [1].

Mütéti indikációt a bal-jobb sönt, a pulmonalis hypertonia mértéke, az AV billentyúk elégtelensége és az emiatt kialakult keringési elégtelenség, illetve a csecsemő fejlődésének elmaradása, a gyakori tüdőinfekciók jelentik.

A mütéti megoldás lehet palliatív vagy rekonstrukciós.

A választandó megoldást meghatározó tényezők: a beteg életkora (koraszülött), testsúlya (2000 g alatti), általános állapota (a súlyos klinikai állapot feltételezhetôen nem tolerálja az extracorporalis mútéti megterhelést), a társuló betegségek (hypoplasiás bal kamra, infekció, egyéb fejlődési rendellenességek stb.), Down-szindróma jelenléte.

Palliatín mütéti megoldás: az arteria pulmonalis törzs beszúkítése, ezzel megelőzendő a pulmonalis hypertonia fixálódását; így biztosított a csecsemő fejlődése, hogy később ideális körülmények között lehessen elvégezni a korrekciós mútétet. A kontraindikációt az AV billentyúk elégtelensége jelenti, mivel a jobb kamrából - az arteria pulmonalis törzs beszükítése miatt - megnő az AV billentyün keresztüli regurgitatio mértéke, csökkentve a perctérfogatot. Ezen esetekben csak a korrekciós mútét jön szóba; a fent említett betegcsoportokban is csak ez a beavatkozás végezhető el, természetesen jelentősen megnövelve a mútét kockázatát (néhány esetben az inoperabilitás kimondását okozva). Ebből következik, hogy ezeket a betegeket 2-4 hónapos korban korrigálni kell, függetlenül a kis súlyuktól, koraszülöttségüktől.

Korrekciós megoldás (az extracorporalis keringés védelmében): folt bevarrásával zárni a kamrai és a primum pitvari septumdefektust (egy- vagy kétfolt-technikával), illetve e foltnak a közös AV billentyúhöz varrásával elkülöníteni és kialakitani a bal és jobb AV szájadékból a mitralis és a tricuspidalis billentyüt. A mitralis billentyü két nagyvitorlarészének egyesülése elmaradt („cleft”), azt pótolni kell $[2,3]$.

\section{A mitralis billentyú sebészete}

Mind a bal AV szájadék, mind a mitralis billentyú elégtelensége vagy stenosisa jelentős szerepet játszik a mütéti indikáció felállításában.

A mitralis billentyú anatómiai felépítése miatt a rekonstrukciója során több szempontot kell figyelembe venni:

l. A bal szájadék (bal kamra) normális nagyságú-e?

2. Hány és milyen fejlettségú papillaris izom van jelen?

3. Az ínhúrok lefutása.

4. Járulékos billentyúk jelenléte.

5. Az egyesítendő nagyvitorlarészek állapota.

1. Ha a mitralis szájadék hypoplasiás, az felveti a bal kamrai hypoplasia lehetőségét - mérlegelendő az „egykamrás korrekció” választása (Fontan-keringés kialakítása). Ezen esetben is meg kell szüntetni a jelentôs mitralis regurgitatiót. Ritka fejlődési rendellenesség a „double orifice" mitralis billentyü, amikor egy nagyobb és egy kisebb elszeparálódott mitralis billentyú található. Ezek inkább szúkülletet, mint regurgitatiót okoznak, de minden esetben egyedileg kell dönteni sorsukról a hemodinamikát befolyásoló szerepük alapján: a) nem kell vele foglalkozni, b) plasztikázni kell, c) múbillentyưre kell cserélni $[4,5]$.

2. Ha csak egy vagy egy domináns papillaris izom van, amelyról indulnak az ínhúrok mindkét vitorlához, „parachute" vitorlát alkotva, kerülni kell a billentyü plasztikázását, mert azonnal vagy a későbbiekben súlyos szúkület alakulhat ki.

3. Az ínhúrok rövidebbre-hosszabbra fejlódése valamelyik vitorla prolapsusát okozhatja, ez megnehezíti vagy lehetetlenné teheti a billentyú komplex plasztikáját.

4. Ezen betegséghez nagy számban társulhat egy vagy két, lateralis elhelyezkedésű járulékos billentyú, melyek megnehezíthetik a plasztikai megoldásokat: a „cleft” elvarrása mellett, a comissurákba helyezett öltésekkel (esetlegesen a járulékos billentyú elzárásával) megszüntetni az itt jelentkező regurgitatiót. Sajnos ezek a beavatkozások oly mértékben szúkíthetik is a szájadékot, hogy jelentős stenosis keletkezhet. Mindig mérlegelni kell, ha nem lehet tökéletes hemodinamikai megoldást elérni, hogy milyen mértékû szúküilettel és/vagy elégtelenséggel tudjuk biztosítani a jelenlegi optimális keringést.

5. A nagyvitorla két részének („cleft”) egyesítésekor gondot jelenthet, hogy ha nagyon vékony a szövet, az egyesítő öltések a jelentős terhelések miatt kiszakadhatnak. A szíven belül a legnagyobb nyomásterhelésnek a mitralis billentyú van kitéve a bal kamra összehúzódásakor. Ezért sajnos a mútét során optimálisnak tûnő varratok a terhelésre a korai posztoperatív szakban már kiszakadhatnak, néha korai reoperációt igé- 
nyelve. Ha vastagok, degeneráltak a szélek, akkor az egyesítés következtében rövidülhet a vitorla, centralis regurgitatiót okozva. A jelen esetben is mérlegelendő a visszaáramlás mértékétől függően a továbblépés szükségessége.

A fent említett problémák kialakulási lehetőségeinek elkerülése miatt létezik egy olyan iskola, mely azt képviseli, hogy ha a kialakított mitralis billentyún nincs regurgitatio, akkor a nagyvitorlán a „cleft” összevarrásától eltekint.

Miután fejlődésben levő csecsemőkről, sokszor kis súlyú koraszülöttekről van szó, minden esetben törekedni kell a plasztikai megoldásra, még annak árán is, hogy csak a keringést „toleráló” kisebb-nagyobb szúkületek vagy regurgitatiók hátrahagyásával lehet a billentyüt rekonstruálni. Ha ez nem lehetséges, akkor múbillentyú beültetése szükséges. Miután a beültetett múbillentyú gátolja a mitralis annulus növekedését, nem mindegy, hogy mikor, mekkora gyermekbe ültetjük azt be, tehát törekedni kell a beavatkozás minél későbbi időpontra való halasztására [6-8].

A mitralis billentyü pótlására mübillentyü beültetése több kérdést vet fel:

a) Milyen típusú billentyưt ültessünk be?

Próbálkozások történtek múérbe varrt pulmonalis autograft mitralis annulusba történő varrásával (Ross-Kabbani-mütét [9, 10]), de ez kis csecsemőknél nehezen kivitelezhető, nem vált be. Felnőttkorban történt próbálkozás sem mutatott kitûnő eredményt (Ross-féle mitralis mütét $[11,12])$.

A biológiai billentyúk „lábai” benyúlnak a bal kamra kiáramlási pályájába (amely a „gooseneck” miatt amúgy is szúkebb), jelentősen szúkítve azt, így bal kamrai elégtelenséget okozhatnak. A legmegfelelőbb billentyú a mechanikus billentyü. Előnye, hogy lapos, kevésbé okoz bal kamrai kiáramlási szúkületet. Hátránya, hogy antikoaguláns terápiát igényel, mely nagy megterhelést, bonyodalmakat (a tápszerek K-vitamin-tartalma stb.) jelent a csecsemők számára.

\section{b) A billentyű méretének megválasztása}

A különböző típusú múbillentyưk mechanikus részét egy varrókeretbe illesztik bele. A varrókeretet lehet rögzíteni a billentyű annulusba/szájadékba. 16 mm-nél kisebb szájadékú múbillentyüt nem érdemes gyártani, mert ennél kisebb billentyúknél már a bevarrt varrókeret okoz jelentős mértékben szúkületet. A csecsemők, különösen a kis súlyú vagy koraszülött csecsemók esetében a mitralis szájadék 8-12 mm-es. Ebbe kell bevarrni a legkisebb, 16 mm-es múbillentyút. Ha jelentős mitralis regurgitatio van, és a keringés kontrolláltan egyensúlyban tartható (lélegeztetôgép, gyógyszeres támogatás stb.), akkor a bal pitvari dilatáció miatt várhatunk az annulus esetleges tágulására. Ha nem, akkor próbálkozni kell az annulus bemetszésével, a lehetséges minimális tágítása után, a bil- lentyú ide történő beültetésével. Ha ez lehetetlen, akkor az annulus elé, a bal pitvarba kell a billentyút bevarrni, ami viszont rosszabb hemodinamikai keringést biztosít, rosszabb eredményhez vezet [6-8].

c) A billentyű sorsa?

Középtávú eredmények: 1) A kis annulusba nehezen beültetett múbillentyú szúkítheti a bal kamrai kiáramlási pályát, és ez az obstrukció progrediálhat. Mivel a mitralis múbillentyút nem lehet kisebbre cserélni, a bal kamrai kiáramlási pályát kell megnagyobbítani. (Ha csak a kiáramlási pálya szúk, de az aortaannuluson az elfolyás akadálytalan, akkor Konno-mútéttel kell a kifolyási pályát tágítani. Ha a billentyú is szúkíti a közvetlen subaorticus régiót, akkor a Ross-Konno-mütét válik szükségessé.) 2) Szerencsés esetben a mitralis billentyü a gyermek 5-7 éves korára okoz oly mértékű szúkületet, hogy a cseréje szükségessé válik. A merev billentyű nem engedi növekedni az annulust, ezért annak minimális tágítási lehetőségeit követően örülhetünk, ha 18-19 mm-es múbillentyüt tudunk beültetni. Minden további billentyúcsere újabb kihívásokat jelent [6-8]. Nagyobb gyermekeknél, felnőtteknél jön szóba a mitralis és az aortabillentyư találkozásánál a pitvar és az aorta megnyitása, az annulusok megnagyobbítása folt bevarrásával, majd a megfeleló méretü, végleges múbillentyưk beültetése [13-17].

\section{Mi a teendö gyermekkorban észlelt esetekben?}

Primer esetben a defectusok zárása mellett ajánlott a mitralis „cleft” zárása is, annak ellenére, hogy valószínüleg nem okozott idáig jelentős problémát. A vastagabb billentyú esetén várhatóan elkerülhető a varratelégtelenség kialakulása. Reoperációk esetén egyedileg kell eldönteni, hogy a billentyű plasztikázható-e még, vagy felnőtt méretü múbillentyưre cserélendő. A mérlegelendő kérdés itt is a gyermek (mitralis szájadék) várható növekedése. Nem eldöntött a kérdés, hogy plasztikai megoldáskor, határesetekben, szabad-e a felnőttkorban „kötelezően” alkalmazandó, mitralis annulusba „ring” beültetése.

\section{Mi a teendófelnött korú betegeknél?}

Primer esetekben törekedni kell a plasztikai megoldásokra. A „cleft” zárása mellett megoldhatók a prolapsusmegszüntetési eljárások is (ékreszekció, ínhúrpótlás stb.), minden esetben kiegészítve ringbeültetéssel. Reoperáció esetén plasztikai megoldások után múbillentyübeültetés, múbillentyû esetén annak cseréje szükséges [18-24]. Napjainkban kezdenek elterjedni a katéteres intervenciós megoldások, ballonfeltágítással transzkatéteres mitralisbillentyü-beültetés, transseptalis vagy hibrid megoldással [25-30].

Külön ki kell emelni e fejlődési rendellenesség Downszindrómával való társulását. A Down-szindrómás betegek 60\%-ához társul veleszületett szívhiba, melyek 90\%-a 
AV septumdefektus (az AV defektus intrauterin felismerése diagnosztikai segítség a Down-szindróma beazonosításához). Érdekessége, hogy a sebészi korrekcióhoz „jobb indulatú anatómiát” alkot, mint a szindróma nélküli betegek esetén, de e betegekben hamarabb és súlyosabb formában alakul ki pulmonalis hypertonia, ezért fiatalabb életkorban igénylik a beavatkozást ( $1-2$ hónapos korban). A szindrómára jellemző „szöveti gyengeség” miatt a kor előrehaladtával gyakrabban jelentkezik/fokozódik a mitralis billentyú elégtelensége. Azzal, hogy napjainkban jelentősen javul e Down-szindrómás betegek életminősége, idős életkort is megélhetnek, így az életkor előrehaladtával várhatóan növekedni fog az igényük a mútéti beavatkozásra [31-33].

\section{Következtetések}

A CAVD korrigálásának legkritikusabb, a beteg sorsát meghatározó része az, hogy hogyan sikerül az AV billentyúből mitralis billentyút kialakítani. Ezt a beavatkozást újszülött-, kora csecsemő korban kell elvégezni, ami többszöri kihívást jelent a szívsebész számára: 1) A fiatal (koraszülött, újszülött) csecsemők nehezen tứrik a hoszszú ideig tartó extracorporalis keringés melletti beavatkozást. 2. A szövetek gyengesége, szakadékonysága, varrhatósága befolyásolja az eredményt. 3) A speciális anatómiai helyzet nem engedi meg minden esetben a tökéletes anatómiai rekonstrukciót, kisebb-nagyobb residuumok (stenosis, insufficientia) fennmaradását el kell fogadni. 4) A kis mitralis annulus miatt kihívást jelent szükség esetén a múbillentyú beültetése. Ezeket a beavatkozásokat nagy gyakorlattal rendelkező, congenitalis szívbetegségeket kezelő sebészek végzik. Gyermek- és felnőttkorban - akár primer beavatkozásként, akár reoperációként válik szükségessé sebészi beavatkozás mindig törekedni kell a plasztikai megoldásra („cleft” zárása, ínhúrplasztika, ékreszekció, ringimplantáció stb.), és csak a legvégső esetben választandó a múbillentyú-beültetés. Ezen beavatkozásokat a nagy tapasztalattal rendelkező szívsebészek végzik. A technika fejlődésének eredményeként a múbillentyúk beültetésénél egyre jelentôsebb számban jelentkeznek a szívkatéteres-intervenciós és hibrid megoldások. A felnőttkort egyre nagyobb számban megélő betegek fokozott problémát jelentenek a kardiológusok és szívsebészek számára.

Anyagi támogatás: A közlemény megírása anyagi támogatásban nem részesült.

Szerzői munkamegosztás: A szerzők azonos mértékben vettek részt az irodalomgyújtésben és a kézirat megírásában. A cikk végleges változatát mindkét szerző elolvasta és jóváhagyta.

Érdekeltségek: A szerzőknek nincsenek érdekeltségeik.

\section{Irodalom}

[1] Hartyánszky IL, Kádár K, Bojeldein, S, et al. Mitral valve anomalies obstucting left ventricular outflow. Eur J Cardiothorac Surg. 1997; 12: 504-506.

[2] Hanley FL, Fenton KN, Jonas RA, et al. Surgical repair of complete atrioventricular canal defects in infancy: twenty-year trends. J Thorac Cardiovasc Surg. 1993; 106: 387-394.

[3] Yamaki S, Yasui H, Kado H, et al. Pulmonary vascular disease and operative indications in complete atrioventricular canal defect in early infancy. J Thorac Cardiovasc Surg. 1993; 106: 398405.

[4] Hartyánszky IL, Lozsádi K, Kádár K, et al. Ebstein’s anomaly and intermediate-form atrioventricular septal defect with double-orifice mitral valve. J Thorac Cardiovasc Surg. 1992; 104: 1496-1497.

[5] Hoohenkerk GJ, Wenink AC, Schoof PH, et al. Results of surgical repair of atrioventricular septal defect with double-orifice left atrioventricular valve. J Thorac Cardiovasc Surg. 2009; 138: 1167-1171.

[6] Hartyánszky I, Mihályi S, Bodor G. Surgical management with mitral valve replacement in young infants with congenital mitral valve diseases and complete atrioventricular septal defect. [Veleszületett mitralisbillentyü-betegség és komplett atrioventricularis septumdefektus sebészi kezelése múbillentyúpótlással csecsemőkorban.] Orv Hetil. 2008; 149: 1891-1894. [Hungarian]

[7] Gandjbakhch I, Lascar M, Pavie A, et al. Intra-atrial insertion of a prosthetic mitral valve. J Cardiovasc Surg. 1988; 29: 113-114.

[8] Opacic D, Efimenko N, Paluszkiewicz L, et al. Intra-atrial neomitral ring creation in the presence of severe mitral annulus calcification. Ann Thorac Surg. 2020; 110: 343-345.

[9] Kabbani SS, Ross DN, Jamil H, et al. Mitral valve replacement with a pulmonary autograft: initial experience. J Heart Valve Dis. 1999; 8: 359-366.

[10] Kabbani SS, Jamil H, Hammoud A, et al. The mitral pulmonary autograft: a follow-up cautionary report. J Heart Valve Dis. 2000; 9: 801-804.

[11] Ross DN. Replacement of aortic and mitral valves with a pulmonary autograft. Lancet 1967; 2(7523): 956-958.

[12] Kabbani SS, Jamil H, Hammoud A, et al. Use of the pulmonary autograft for mitral replacement: short- and medium-term experience. Eur J Cardiothorac Surg. 2001; 20: 257-261.

[13] Manouguian S, Abu-Aishah N, Neitzel J. Patch enlargement of the aortic and mitral valve rings with aortic and mitral double valve replacement. Experimental study. J Thorac Cardiovasc Surg. 1979; 78: 394-401.

[14] Manouguian S, Seybold-Epting W. Patch enlargement of the aortic valve ring by extending the aortic incision into the anterior mitral leaflet. New operative technique. J Thorac Cardiovasc Surg. 1979; 78: 402-412.

[15] Rastan H, Atai M, Hadi H, et al. Enlargement of mitral valvular ring. New technique for double valve replacement in children or adults with small mitral annulus. J Thorac Cardiovase Surg. 1981; 81: 106-111.

[16] Krasopoulos G, David TE, Armstrong S. Custom-tailored valved conduit for complex aortic root disease. J Thorac Cardiovasc Surg. 2008; 135: 3-7.

[17] Lad VS, Newcomb AE, Davis PJ, et al. Surgical techniques for the management of the 'hostile mitral annulus'. Heart Lung Circ. 2014; 23: 217-223.

[18] Hartyánszky I, Székely A, Király L, et al. Surgical management of congenital heart defects in adolescent and adult patients, between years 2001-2008. [Tapasztalataink a fiatal- és felnőttkori veleszületett szívhibák sebészi kezelésében 2001-2008.] Orv Hetil. 2009; 150: 1739-1743. [Hungarian]

[19] Hartyánszky I, Varga S, Havasi K, et al. Perspectives in the management of congenital heart defects in adult patients. [Perspek- 
tívák a veleszületett szívhibák felnőttkori sebészi kezelésében.] Orv Hetil. 2015; 156: 92-97. [Hungarian]

[20] Havasi K, Kalapos A, Berek K, et al. More than 50 year's experience in the treatment of patients with congenital heart disease in a Hungarian university hospital. The basics of the CSONGRAD Registry. [Több mint 50 év tapasztalat a congenitalis szívbetegek ellátásában egy magyar egyetemi központban. A CSONGRÁD Regiszter alapadatai.] Orv Hetil. 2015; 156: 794-800. [Hungarian]

[21] Hartyánszky I, Varga S, Csepregi L, et al. Surgical management of congenital heart defects beyond the age of 60 . [Veleszületett szívhibák sebészi kezelése 60 éves kor felett.] Orv Hetil. 2016 157: 820-824. [Hungarian]

[22] Bianchi G, Bevilacqua S, Solinas M, et al. In adult patients undergoing redo surgery for left atrioventricular valve regurgitation after atrioventricular septal defect correction, is replacement superior to repair? Interact Cardiovasc Thorac Surg. 2011; 12: 1033-1039.

[23] Hoohenkerk GJ, Bruggemans EF, Koolbergen DR, et al. Longterm results of reoperation for left atrioventricular valve regurgitation after correction of atrioventricular septal defects. Ann Thorac Surg. 2012; 93: 849-855.

[24] Moran AM, Daebritz S, Keane JF, et al. Surgical management of mitral regurgitation after repair of endocardial cushion defects. Early and midterm results. Circulation 2000; 102(19 Suppl 3): $160-165$.

[25] Guerrero M, Dvir D, Himbert D, et al. Transcatheter mitral valve replacement in native mitral valve disease with severe mitral annular calcification: results from the first multicenter global registry. J Am Coll Cardiovasc Interv. 2016; 9: 1361-1371.

[26] Guerrero M, Urena M, Himbert D, et al. 1-year outcomes of transcatheter mitral valve replacement in patients with severe mitral annular calcification. J Am Coll Cardiol. 2018; 71: 18411853.

[27] Marcus SG, Mahadevan VS, Deuse T. Hybrid open minimally invasive transcatheter mitral valve replacement. Ann Thorac Surg. 2018; 106: 57-59.
[28] Castillo JG, Tang GH, Adams DH, et al. Hybrid mitral valve replacement: a heart-team approach to severe mitral annular calcification. J Am Coll Cardiol Case Rep. 2019; 1: 495-499.

[29] Romero DN, Fortunato GA, Stöger G, et al. Balloon-expandable transcatheter mitral valve replacement through minimally invasive approach in Big MAC. November 2020. Doi: 10.25373/ ctsnet.13242311.

[30] Van Hemelrijck M, Taramasso M, Gülmez G, et al. Mitral annular calcification: challenges and future perspectives. Indian J Thorac Cardiovasc Surg. 2020; 36: 397-403.

[31] Hartyánszky I, Dobos M, Szabolcs J, et al. Life expectancy in Down's syndrome infants and children with congenital heart defects 1974-1997. [A Down-szindrómás szívbeteg csecsemók és gyermekek életkilátásai 1974-1997 között.] Orv Hetil. 2000, 141: 2119-2122. [Hungarian]

[32] Hartyánszky I, Lozsádi K, Király L, et al. Results and prognois of surgical management of complete atrioventricular septal defect in Down's syndrome patients. [Down-szindrómás betegek komplett atrioventricularis septum defektusának sebészeti eredményei és prognózisa.] Cardiol Hung. 2000; 29: 145-148. [Hungarian]

[33] Hartyánszky I, Bogáts G. Change in our approach in the surgical management of congenital heart defects in patients with Down syndrome, 1974-2016. [Szemléletváltozás a Down-szindrómás szívbetegek szívsebészeti kezelésében, 1974-2016.] Orv Hetil. 2016; 157: 1601-1603. [Hungarian]

(Hartyánszky István dr., Szeged, Semmelweis u. 8., 6725 e-mail: hartyanszky@hotmail.com)

Budajenői háziorvosi praxis eladó. Érdeklődés a +36 30476 4014-es telefonszámon.

A cikk a Creative Commons Attribution 4.0 International License (https://creativecommons.org/licenses/by/4.0/) feltételei szerint publikált Open Access közlemény, melynek szellemében a cikk bármilyen médiumban szabadon felhasználható, megosztható és újraközölhető, feltéve, hogy az eredeti szerzỏ és a közlés helye, illetve a CC License linkje és az esetlegesen végrehajtott módosítások feltüntetésre kerülnek. (SID_1) 